\title{
A LOJALITÁS DIMENZIÓINAK LONGITUDINÁLIS MÉRÉSE A HAZAI LAKOSSÁGI ENERGIAFOGYASZTÓK KÖRÉBEN FAKTORANALÍZIS ALAPJÁN
}

Az utóbbi évtizedekben számos nemzetközi tanulmány figyelmeztetett arra, hogy a jó minőség és a fogyasztói elégedettség nem elég a cégek profitjának növeléséhez, hanem sokkal inkább a lojalitást, a hűséget kell a középpontba állítani. Bár a kilencvenes évek végén már több kutatás eredményei megkérdőjelezték a minőség-elégedettség-lojalitás-jövedelmezőség lánc szilárd logikáját, a kapcsolatot leíró modelleket és mérési eljárásokat továbbra is használják a kutatásokban. A szerzők dolgozatukban két kutatás eredményei alapján e témakörrel foglalkoznak. ${ }^{1}$

A fogyasztói elégedettség hazai szakirodalma az elmúlt néhány évben ígéretesen bővült (Némethné, 2000; Fojtik - Farkas, 2001; Hofmeister et al., 2003, és e kérdésben gyakoriak az empirikus kutatások is (Rekettye - Tersztyánszky, 1997; Rekettye et al., 1997; Szántó, 2003). Ezzel szemben alig találkozhatunk a lojalitás kérdéskörét érintő tanulmányokkal, az empirikus kutatások publikált eredményei pedig e területen szerények (Rekettye - Hetesi, 2001; Hetesi, 2002, 2003; Veres - Hetesi, 2003). A minőség-elégedettséglojalitás-jövedelmezőség lánc minden elemének összefüggésére, azaz annak vizsgálatára, hogy a lojalitás valóban jövedelmezőséghez vezet-e, nem ismerünk hazai kutatási jelentéseket, márpedig kívánatos lenne a szakirodalomban is vitatott összefüggések hazai empirikus vizsgálatokon történő ellenőrzése.

Tanulmányunkban a hazai lakossági energiafogyasztók lojalitására ható tényezők longitudinális kutatásainak eredményeit foglaljuk össze, és kísérletet teszünk a minőség-elégedettség-lojalitás kapcsolat összehasonlító elemzésére. A fenti kapcsolatok kutatására a kérdőíves adatfelvételeket 2000-ben ezerfős regionális háztartási, míg 2002-ben ezerfős országos háztartási mintán végeztük a hazai energiaszolgáltató szférában, de sajnos arra nem volt lehetőségünk, hogy

1 A tanulmány a Pécsi Tudományegyetem Marketing tanszékén folyó T37855 számú OTKA kutatás részeként készült. azt is vizsgáljuk, miként hat a lojalitás a jövedelmezőségre.

\section{A kutatások lebonyolítása}

\section{A lakossági fogyasztók lojalitásának regionális vizsgálata 2000}

Az első empirikus kutatásra 2000-ben került sor egy magyarországi (47\%-ban külföldi szakmai befektetôvel rendelkező) áramszolgáltató szervezetnél a dél-alföldi régióban. A vizsgálat során kiinduló problémának tekintettūk, hogy a liberalizáció előtt álló cégek számára a piacok felszabadítása után az egyik legfontosabb kérdés az lesz, hogy miként tudják megtartani fogyasztóikat, miként tudnak kialakítani egy lojális, hűséges fogyasztói bázist. Reicheld és szerzőtársa kutatásai bizonyították, hogy az új fogyasztó megszerzése mindig drágább, mint a meglévő megtartása (Reicheld - Sasser, 1990), és mások is felhívták a figyelmet a vevőmegtartás jövedelmezőségére, arra, hogy a lojális vevőkör kialakítása lényegesen kevesebb ráfordítással jár, mint az akvizíció (Fornell - Wernerfelt, 1987).

A fenti állítások mellett megítélésünk szerint az energiaszolgáltatók speciális helyzetben vannak: a piac többnyire telített, annak bővítésére alig van lehetőség, az újonnan belépő versenytársak pedig a meg- 
lévő fogyasztók elcsábításával juthatnak nagyobb piaci részesedéshez, azaz a liberalizációt követően várhatóan éles küzdelem kezdődik majd a fogyasztókért. Fontosnak tartottuk tehát annak vizsgálatát, vajon milyen tényezők befolyásolják a lakossági fogyasztók lojalitását, azaz mire kell majd a jövőben nagyobb hangsúlyt fektetniük az energiaszolgáltatóknak.

A kutatási modell kialakításánál elsősorban a szakirodalomban már részben bizonyított összefüggésekre támaszkodtunk (Gallup, 1994; Oliver, 1999; Neal, 1999; Martensen et al, 2000), de a vizsgált terület specialitásai és a sajátos magyarországi környezeti feltételek következtében új elemeket is tartalmazott a vizsgálat. A kutatási koncepciót az 1 . ábrán látható modellben foglaltuk össze.

1. ábra

A lojalitásra ható tényezők

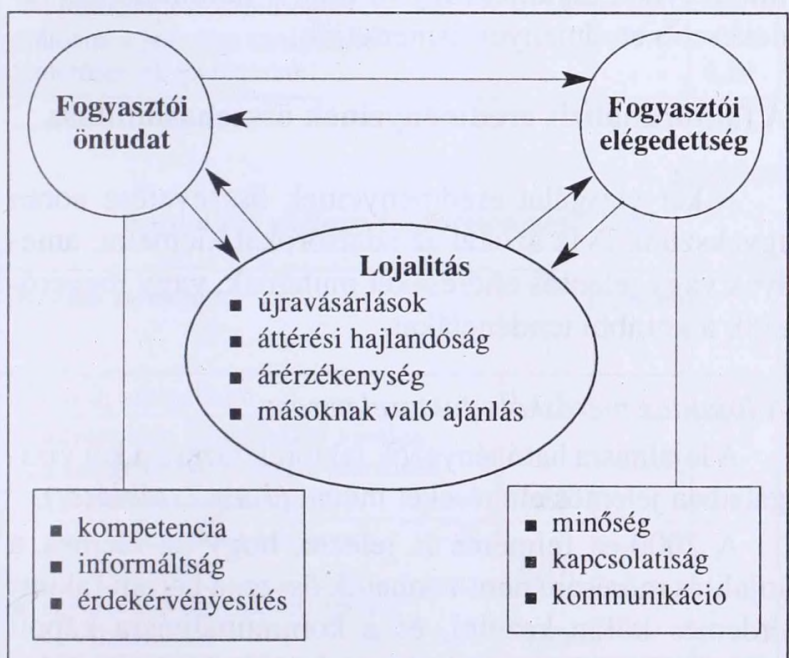

Forrás: Hetesi (2001)

Az alkalmazott modellekből átvettük a fogyasztói elégedettség vizsgálati módszereit, és feltételeztük, hogy a minőséggel való elégedettség növeli az általános elégedettséget, az pedig pozitív hatással van a lojalitásra. Bár a minőség-elégedettség-lojalitás lánc kapcsolatot számtalan elméleti tanulmány és empirikus kutatás megkérdőjelezte (Reicheld, 1996; Oliver, 1999; Neal, 1999; Zeithaml, 2000; Vollmer et al., 2000), legalább ennyi cikk szól a pozitív kapcsolatról (Jones - Sasser, 1995; Grönholdt et al, 2000; Martensen et al, 2000). Tekintettel a magyarországi sajátos viszonyokra úgy gondoltuk, hogy a térségben a minőség-elégedettség-lojalitás lánc logikája értelmezhető.

A minőségen kívül az elégedettséget mérő változónak tekintettük a fogyasztó és a cég közötti kap- csolatok milyenségét, hazánkban ugyanis a fogyasztóval való bánásmód különös jelentősséggel bír még a versenyszférában is, nem beszélve a monopolhelyzetben lévő cégekről. Egy néhány éve készült hazai kutatás eredményei is jelzik, hogy bár a magyarországi fogyasztók éreznek bizonyos javulást az ügyfél-orientáltság területén, de több esetben továbbra sem tapasztalható pozitív elmozdulás (Rekettye, 2000).

Az elégedettség méréséhez szükségesnek tartottuk a kommunikáció megítélésének mérését is, ugyanis a közüzemi szolgáltatók az elmúlt években gyakorlatilag alig kommunikáltak fogyasztóikkal, és napjainkban is csak korlátozottan jelennek meg az ilyen irányú erőfeszítések. A fentiek következtében a kommunikációs eszközök alkalmazása a fogyasztók számára is szokatlan jelenség, így annak vizsgálatát az elégedettség és a lojalitás alakulásában fontosnak tartottuk.

$\mathrm{Az}$ ismert modellekhez képest új elemként jelent meg a 2000. évi kutatásban a fogyasztói öntudat hatásának mérése a lojalitásra. A kompetencia, informáltság, érdekérvényesítés kérdésének vizsgálata talán meglepő és értelmezhetetlen a mindig is versenypiaci körülmények között működő országokban, ahol azonban a fogyasztóknak évtizedekig a választásra sem volt lehetőségük, ott ezek a kérdések bizony elemi erővel merülnek fel a megváltozott körülmények között. Kétségtelen, hogy az energiaszektorban még ma sincs meg a szabad választás lehetősége, ám a korábbiakban lezajlott (privatizáció, piacok telítődése, relatív verseny kialakulása, az árak folyamatos emelkedése) és a várható változások (piacnyitás, versenyhelyzet kialakulása) következtében a fogyasztók eǵyre többet és többet akarnak tudni arról, hogy mit is kapnak a pénzükért, és ahogy az információk növekednek, úgy nő az érdekérvényesíti hajlandóság és képesség is.

A lojalitás latens változó mérésére a legtöbb nemzetközi kutatás négy elemet tart szükségesnek (újravásárlási szándék, keresztvásárlások, árérzékenység, másoknak való ajánlás) (Neal, 1999; Grönholdt et al, 2000; Zeithalm, 2000; Vollmer et al., 2000), de pl. a Gallup QSA modellje szerint más tételekkel mérhető a lojalitás: általános elégedettség, újravásárlás, másoknak való ajánlás, árérzékenység (Gallup, 1994).

A vizsgált energiaszolgáltató esetében a modellben kissé átalakítottuk a már bevezetett mérési dimenziókat. Egyrészt kihagytuk a keresztvásárlási tételt (esetünkben ugyanis ugyanattól a cégtől nem vásárolhat más szolgáltatást a fogyasztó), másrészt nem e változó kapcsán vizsgáltuk az elégedettséget, hanem azt külön dimenzióként kezeltük, harmadrészt a cég elhagyásának olyan aspektusait is vizsgáltuk, amelyek 
nem csak az árváltozással, hanem egyéb szolgáltatásminőség változásokkal kapcsolatosak (pl. szélesebb választék, jobb tájékoztatás, egyszerűbb ügyintézés).

A 2000. évi regionális kutatás 1000 fős reprezentatív lakossági mintán személyes kérdőíves módszerrel történt egy magyarországi áramszolgáltató cég ellátási területén. A reprezentatív háztartási mintán végzett vizsgálat eredményei több olyan kérdésre hívták fel a figyelmet, amelyek arra ösztönöztek, hogy a kutatást megismételjük, és ellenőrizzük az eredmények megbízhatóságát.

A skálák tesztelése és a faktorelemzések eredményei alapján valószínűsíthető volt, hogy a nemzetközileg bevált technikák a közép-kelet-európai régióban kellő körültekintést igényelnek, és a módszerek adaptálása során szükséges az adott ország, az adott ágazat és az adott kutatási probléma függvényében bizonyos módosításokkal élni.

\section{A lakossági fogyasztók lojalitásának országos vizsgálata 2002}

Második vizsgálatunkra két év elmúltával került sor, melynek körülményei részben azonosak, részben eltértek a 2000-es felméréshez képest.

Tartalmi szempontból azonosságnak tekinthető, hogy mindkét vizsgálatnál ugyanaz volt a problémafelvetés és ugyanazt a kiinduló modellt alkalmaztuk, valamint ugyanazokat a hipotéziseket fogalmaztuk meg. Feltételeztük, hogy minél elégedettebbek a fogyasztók az energiaszolgáltatás minőségével, annál erősebb a fogyasztói lojalitás. További hipotézisünk volt, hogy minél elégedettebbek a fogyasztók az energiaszolgáltatók számlázási és ügyfélszolgálati tevékenységével, annál magasabbra értékelik a minőséget és annál lojálisabbak a szolgáltató iránt, valamint feltételeztük, hogy a fogyasztói öntudat is befolyásolja a hűséget.

Módszertani szempontból azonos célcsoportban (lakossági fogyasztók), azonos méretű mintán (1000 fő) és azonos módszerrel (személyes kérdőíves megkérdezés) zajlott az adatfelvétel, ám az alkalmazott kérdőív tekintetében már nagyobbak a különbségek. Egyrészt a 2000. évben használt kérdőív egyes kérdései a Cronbach alfa értékei miatt kiestek az új vizsgálatból, másrészt az elégedettségi dimenziót a MEH által évek óta használt standard kérdőív elemeivel mértük, amelyek több ponton eltérnek a 2000-es kérdésektől (Rekettye Tersztyánszky, 1997; Orosdy - Rekettye, 2003).

A kutatás megbízhatóságát tovább csökkenti, hogy a két vizsgálat között eltelt időszakban jelentősen megváltoztak a piaci körülmények, a piacnyitás következményeit már jobban ismerték a fogyasztók, és ez befolyásolhatta a válaszokat.

Az érvényességi követelményt sérti, hogy néhány kérdést más megfogalmazásban tettünk fel, így az azokban használt fogalmak jelentéstarta!ma is megváltozhatott, és ez is módosulásokat eredményezhetett a válaszokban.

A fenti változtatásokat is figyelembe véve kutatásunk egyik célja az volt, hogy megnézzük, vajon a regionális és országos eredmények között milyen azonosságok, illetve hasonlóságok mutathatók ki, a faktorelemzések elkülönülései milyen tendenciákat mutatnak, és a lojalitásra ható tényezők mérésére alkalmazott skálák valóban használhatók-e?

További célként tűztük ki a modell tényezőinek regresszió elemzéséből levonható következtetések vizsgálatát, valamint a klaszterelemzést. Jelen tanulmány keretei nem teszik lehetővé, hogy a hármas cél mindegyikét taglaljuk, így itt csak a faktoranalízis érdekesebb eredményeit ismertetjük.

\section{A faktoranalízis eredményeinek összehasonlítása}

A két vizsgálat eredményeinek összevetése során igyekszünk csak azokat az adatsorokat kiemelni, amelyek vagy jelentős eltéréseket mutatnak, vagy megerősítik a korábbi tendenciákat.

\section{A lojalitás mérőskála faktorelemzése}

A lojalitásra ható tényezők faktorelemzése a két vizsgálatban jelentôs eltéréseket mutat. (1. és 2. táblázat).

A 2000-es felmérés is jelezte, hogy az elemek a lojalitás mérésére nem vonhatók össze, a három faktort érdemes külön kezelni, és a kommunalitásra kapott adatokból is látható volt, hogy ,az újravásárlási szándék és a másoknak való ajánlás" kérdések kissé kilógnak a sorból, azaz a faktorok ezt a két változót nem tudták meggyőzően megjeleníteni.

A két évvel ezelőtti gyanúnk beigazolódott a kontroll kutatás során. Bár a „másoknak való ajánlás” kérdést átfogalmaztuk, és ez gyengítette mind a megbízhatósági, mind a validitási követelményeket, ám mégis megfontolandó, hogy a lojalitástényezők együttes faktorelemzése csak az árérzékenység kapcsán mutat hasonlóságokat.

A faktoranalízis eredményei a fentiek alapján nehezen értelmezhetők, így a korábbi kutatásnál bizonytalan egyik elem elhagyásával is elvégeztük az elemzést (3. táblázat).

A faktoranalízis itt már csak két faktort jelez, amelyek tartalmilag elkülöníthetők ugyan, de azt minden- 
1. táblázat

A lojalitás változó faktorelemzése $\mathbf{2 0 0 0}$

\begin{tabular}{|c|c|c|c|}
\hline \multirow[t]{2}{*}{ Kérdés tartalma } & \multicolumn{3}{|c|}{ Faktorok } \\
\hline & 1 & 2 & 3 \\
\hline \multicolumn{4}{|l|}{ Ha az új szolgáltató: } \\
\hline $\begin{array}{l}\text { - egyszerűbb ügyintézést ígérne, } \\
\text { ôt választanám }\end{array}$ & 0,94 & & \\
\hline $\begin{array}{l}\text { - jobb tájékoztatást nyújtana, } \\
\text { ôt választanám }\end{array}$ & 0,91 & & \\
\hline $\begin{array}{l}\text { - szélesebb választékot kínálna, } \\
\text { ôt választanám }\end{array}$ & 0,85 & 0,23 & \\
\hline $\begin{array}{l}\text { - 10\%-kal olcsóbban kínálná a } \\
\text { szolgáltatást, ốt választanám }\end{array}$ & & 0,91 & \\
\hline $\begin{array}{l}\text { - 5\%-kal olcsóbban kínálná a } \\
\text { szolgáltatást, ốt választanám }\end{array}$ & & 0,90 & \\
\hline $\begin{array}{l}\text { - ugyanolyan feltételekkel kínálná } \\
\text { a szolgáltatást, biztosan maradnék } \\
\text { a jelenlegi szolgáltatónál }\end{array}$ & & & 0,82 \\
\hline $\begin{array}{l}\text { Ha több más szolgáltató lenne a } \\
\text { piacon változatlan feltételekkel, } \\
\text { Ön mekkora valószínűséggel } \\
\text { ajánlaná a jelenlegi szolgáltatót } \\
\text { ismerőseinek, barátainak? }\end{array}$ & & & 0,79 \\
\hline
\end{tabular}

2. táblázat

A lojalitás változó faktorelemzése 2002

\begin{tabular}{|c|c|c|c|}
\hline \multirow[t]{2}{*}{ Kérdés tartalma } & \multicolumn{3}{|c|}{ Faktorok } \\
\hline & 1 & 2 & 3 \\
\hline \multicolumn{4}{|l|}{ Ha az új szolgáltató: } \\
\hline $\begin{array}{l}\text { - ugyanolyan feltételekkel kínálná } \\
\text { a szolgáltatást, biztosan maradnék } \\
\text { a jelenlegi szolgáltatónál }\end{array}$ & 0,82 & & \\
\hline $\begin{array}{l}\text { - jobb tájékoztatást nyújtana, } \\
\text { ôt választanám }\end{array}$ & 0,77 & & \\
\hline $\begin{array}{l}\text { - egyszerúbb ügyintézést ígérne, } \\
\text { ôt választanám }\end{array}$ & 0,69 & & \\
\hline $\begin{array}{l}\text { - 10\%-kal olcsóbban kínálná a } \\
\text { szoolgáltatást, ôt választanám }\end{array}$ & & 0,93 & \\
\hline $\begin{array}{l}\text { - 5\%-kal olcsóbban kínálná a } \\
\text { szolgáltatást, ốt választanám }\end{array}$ & & 0,86 & \\
\hline $\begin{array}{l}\text { - szélesebb válásztékot kínálna, } \\
\text { ôt választanám }\end{array}$ & & 0,51 & 0,49 \\
\hline $\begin{array}{l}\text { Ha több más szolgáltató lenne a } \\
\text { piacon változatlan felttételekkel, } \\
\text { Ön mekkora valószínűséggel } \\
\text { ajánlaná a jelenlegi szolgáltatót } \\
\text { ismerőseinek, barátainak? }\end{array}$ & 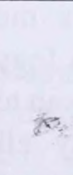 & & 0,90 \\
\hline
\end{tabular}

képpen jelzik, hogy a lojalitás mérésére - legalábbis az általunk vizsgált szektorban - valószínűsíthetően más elemeket is célszerű használni.

\section{A minőség méröskála faktorelemzése}

Mint azt már említettük a két kutatás módszertani különbségeinél, ezt a változót jelentősen eltérő kérdésekkel mértük. A 2000. évben végzett vizsgálatnál a
3. táblázat

A lojalitás változó faktorelemzése $2002 *$

\begin{tabular}{|c|c|c|}
\hline \multirow[t]{2}{*}{ Kérdés tartalma } & \multicolumn{2}{|c|}{ Faktorok } \\
\hline & 1 & 2 \\
\hline \multicolumn{3}{|l|}{ Ha az új szolgáltató: } \\
\hline $\begin{array}{l}\text { - 5\%-kal olcsóbban kínálná a szolgáltatást, } \\
\text { ôt választanám }\end{array}$ & 0,90 & \\
\hline $\begin{array}{l}\text { - 10\%-kal olcsóbban kínálná a szolgáltatást, } \\
\text { ôt választanám }\end{array}$ & 0,86 & \\
\hline - egyszerủbb ügyintézést ígérne, ốt választanám & & 0,78 \\
\hline $\begin{array}{l}\text { - ha több más szolgáltató lenne a piacon } \\
\text { változaflan feltételekkel, Ön mekkora } \\
\text { valószínűséggel ajánlaná a jelenlegi } \\
\text { szolgáltatót ismerôseinek, barátainak? }\end{array}$ & & 0,75 \\
\hline - jobb tájékoztatást nyújtana, ôt választanám & & 0,73 \\
\hline - szélesebb választékot kínálna, őt választanám & & 0,68 \\
\hline
\end{tabular}

gyakran alkalmazott SERVQUAL módszer (minőség = fontosság *(teljesítmény-elvárások) helyett (Parasuraman et al., 1988) a mérésre az egyszerúbb SERVPERF módszert választottuk, ahol a minőség egyenlő a teljesítménnyel (Cronin - Taylor, 1992) és a minőség dimenzióit az energiaszolgáltatók specialitásai miatt az eredeti 22 elemből csak 15 elemmel mértük. Az önálló változóként értelmezett „kapcsolat” változóba került át néhány hagyományos minőségmérő elem, és ez a változó néhány új tétellel bővült. Ezzel szemben a 2002-es felmérés a fontosság-elégedettség módszert használta, és itt is jelentősen átalakultak az elemek. Éppen ezért e dimenzióban mellőzzük az adatok részletes elemzését, és csak a legfontosabb következtetéseket említjük meg.

A fentiekben elmondottak alapján 2000-ben a 15 elemű skála az alábbi tételekből állt össze (4. táblázat).A faktoranalízis alapján az elemek két faktorba különíthetők el, mégpedig oly módon, hogy az első faktorba került szinte minden „tradicionális" minőségtényező (tárgyi környezet, megbízhatóság, bizalom, reagálási készség), míg a másodikban magas faktorsúllyal az egyéni igények megértése és az érdekek figyelembevétele szerepel (empátia).

Regionális kutatásunk faktorelemzésének eredményei valószínűsítették, hogy a szolgáltatások minőségi dimenzióinak vizsgálata nem standardizálható, és a mérések tételeit célszerủ az adott gazdasági környezethez és az ágazati sajátosságokhoz igazítani. A fentiek következtében 2002-ben az elégedettségi mutatók között az energiaszolgáltatás speciális minőségi tényezői szerepeltek, és ezek faktorelemzése már sokkal inkább tükrözi az ágazat sajátosságait, mint a 22 dimenziós Parasuraman-modell (Parasuraman et al., 1985) (5. táblázat). 
A minőség skála faktorelemzése $\mathbf{2 0 0 0}$

\begin{tabular}{|l|c|c|}
\hline \multirow{2}{*}{ Kérdés tartalma } & \multicolumn{2}{|c|}{ Faktorok } \\
\cline { 2 - 3 } & 1 & 2 \\
\hline Az alkalmazottak szakmailag felkészültek & $\mathbf{0 , 7 8}$ & 0,25 \\
\hline A szolgáltató mindig pontosan teljesíti ígéreteit & $\mathbf{0 , 7 5}$ & 0,32 \\
\hline $\begin{array}{l}\text { A szolgáltató múszaki színvonala, technikai } \\
\text { felszereltsége megfelelő }\end{array}$ & $\mathbf{0 , 7 5}$ & 0,20 \\
\hline $\begin{array}{l}\text { A szolgáltatással kapcsolatos anyagok } \\
\text { (hírlevelek, szórólapok, újságok) } \\
\text { szépek, esztétikusak }\end{array}$ & & \\
\hline A szolgáltató alkalmazottai jó megjelenésúek & $\mathbf{0 , 7 4}$ & \\
\hline $\begin{array}{l}\text { A problémák megoldását illetôen biztonságban } \\
\text { érezhetem magam }\end{array}$ & $\mathbf{0 , 7 4}$ & 0,39 \\
\hline $\begin{array}{l}\text { A szolgáltató hibátlanul teljesíti az adott } \\
\text { szolgáltatást }\end{array}$ & $\mathbf{0 , 7 3}$ & 0,38 \\
\hline A hibaelhárítás szakszerű, megbízható & $\mathbf{0 , 7 3}$ & 0,36 \\
\hline $\begin{array}{l}\text { Ha hibát jelentek be a szolgáltatással } \\
\text { kapcsolatban, azonnal kapok valamilyen választ }\end{array}$ & $\mathbf{0 , 7 0}$ & 0,43 \\
\hline $\begin{array}{l}\text { A szolgáltató alkalmazottai figyelmesek, } \\
\text { szolgálatkészek }\end{array}$ & $\mathbf{0 , 6 9}$ & 0,42 \\
\hline $\begin{array}{l}\text { A szolgáltató mindig jelzi, hogy mikor végzi } \\
\text { el a szükséges munkát }\end{array}$ & $\mathbf{0 , 6 6}$ & 0,38 \\
\hline $\begin{array}{l}\text { A szolgáltató munkatársai azonnal reagálnak } \\
\text { a kérésekre }\end{array}$ & $\mathbf{0 , 6 5}$ & 0,48 \\
\hline $\begin{array}{l}\text { A szolgáltatással kapcsolatos anyagok } \\
\text { (hírlevelek, szórólapok, újságok) mindig } \\
\text { érthetőek }\end{array}$ & $\mathbf{0 , 5 5}$ & \\
\hline $\begin{array}{l}\text { A szolgáltató alkalmazottai az egyéni } \\
\text { igényeket is megértik }\end{array}$ & & $\mathbf{0 , 8 8}$ \\
\hline $\begin{array}{l}\text { A szolgáltató figyelembe veszi a fogyasztók } \\
\text { érdekeit }\end{array}$ & $\mathbf{0 , 8 5}$ \\
\hline
\end{tabular}

$\mathrm{Az}$ elemek elrendeződése más, a két faktor tartalmilag nehezen magyarázható, bár annyi látható, hogy az első faktorban döntően az alkalmazottak fizikai megjelenésével kapcsolatos elemek szerepelnek, míg a másodikban a tájékoztatás jellemzőit találjuk. Az óraleolvasás időpontjáról való tájékoztatás kilóg a sorból, de a két faktor magyarázó ereje erős: az első faktor 55\%-ban, a második 45\%-ban magyarázza a minőséget.

\section{Az üzemszerü kapcsolat mérőskála faktorelemzése}

Kiinduló modellünk a lojalitásra ható önálló dimenzióként értelmezi a kapcsolatiságot, amelynek jelentőségét az elkötelezettség kialakításában a marketing-szakirodalom nagyon fontosnak tartja. A ,relationship marketing" képviselői szerint a vevők lojalitásának megszerzéséért folytatott harcban azok fognak versenyelőnyökhöz jutni, akik képesek a fogyasztókkal hosszú távú kapcsolatokat kialakítani (Berry, 1980; Grönroos, 1994; Gumesson, 1994). A kapcsolati marketing definiálása sem egyértelmű a szakirodalomban, de a szerzők többsége a hosszú távú
A minőség skála faktorelemzése 2002

\begin{tabular}{|l|c|c|}
\hline \multirow{2}{*}{ Mennyire elégedett } & \multicolumn{2}{|c|}{ Faktorok } \\
\cline { 2 - 3 } & 1 & 2 \\
\hline Az áramszolgáltató szerelőjének udvariasságával & 1,00 & \\
\hline A leolvasó udvariasságával, segítőkészségével & 1,00 & \\
\hline A leolvasó szakmai felkészültségével & 0,98 & \\
\hline A leolvasó azonosíthatóságával & 0,88 & \\
\hline $\begin{array}{l}\text { Az áramszolgáltató szerelőjének szakmai } \\
\text { felkészuultségével }\end{array}$ & 0,88 & \\
\hline Az áramszolgáltató szerelőjének megjelenésével & 0,88 & \\
\hline A leolvasó megjelenésével & 0,88 & \\
\hline A szolgáltatás helyreállításának gyorsaságával & 0,88 & \\
\hline A hiba okairól történő tájékoztatással & & 1,00 \\
\hline $\begin{array}{l}\text { A szolgáltatás helyreállításának várható } \\
\text { időtartamáról szóló tájékoztatással }\end{array}$ & & 1,00 \\
\hline $\begin{array}{l}\text { Az óraleolvasás pontos időpontjáról való } \\
\text { tájékoztatással }\end{array}$ & & $-1,00$ \\
\hline A hibafelvevő gyors elérhetôségével & & 0,93 \\
\hline $\begin{array}{l}\text { Az előre tervezett áramszünetekről való } \\
\text { tájékoztatással }\end{array}$ & & 0,85 \\
\hline $\begin{array}{l}\text { Az áramszolgáltató szerelőjének } \\
\text { azonosíthatóságával }\end{array}$ & & 0,74 \\
\hline
\end{tabular}

profit biztosítékát a hosszú távú kapcsolatok kialakításában, fenntartásában és fejlesztésében látja. A vásárló hűséges lesz, ha a kapott szolgáltatás értékét relatíve többnek érzi, mint a versenytársakét, de a fogyasztók általában személyre szabott és szoros kapcsolatot igényelnek a szolgáltatóval (Parasuraman et al, 1991). A szolgáltató szervezetek számára szükségessé válik, hogy ne csak a rövid távú pénzügyi célokat határozzák meg, hanem egyre fontosabb a hosszú távú „kapcsolati érték” megteremtése. A „kapcsolati érték" paradigma (fogyasztó és dolgozó; fogyasztó és szolgáltató; dolgozó és szolgáltató stb. között) ma sokkal nagyobb jelentőséggel bír, mint valaha (Kandampully, 1998).

$\mathrm{Az}$ üzemszerủ kapcsolat dimenzió külön mérésével a hazai felmérésekben is találkozhatunk (Rekettye et al., 1997; Gallup, 2000), melyek kapcsán a vizsgálat tárgyát képezik azok a mechanizmusok, amelyek többnyire folyamatosak a fogyasztók számára. Ilyen pl. a számlázás, amely olyan tényezőként jelenik meg az ügyfelek számára, amely elkerülhetetlen, az ügyfélszolgálati irodák tevékenységével pedig akkor találkoznak a fogyasztók, ha a szolgáltatást igénybe kívánják venni, vagy ha azzal kapcsolatban problémáik merülnek fel. A már alkalmazott skálák és az előzetes tesztelések alapján az operacionalizálás és az eredmények a 6. és a 7. táblázatban rögzítettek szerint alakultak.

A faktoranalízis alapján az üzemszerű kapcsolat skálája nem egydimenziójú, az elemek három faktorba 
különülnek el. Az egyes faktorokba került tételek tartalmilag jól magyarázhatók, hiszen az első faktorba az ügyfélszolgálati ügyintézés minőségének megítélése került, a második faktorban az elérhetőségi elemek szerepelnek, míg a számlázás értékelése külön faktort képez.

A kutatás eredményei alapján az üzemszerű kapcsolat látens változó három dimenzióra bontható:

- az ügyfélszolgálati dolgozók munkájának értékelése,

- a szolgáltató elérhetősége,

- a számlázási tevékenység.

Az országos kutatás eredményei alapján az üzemszerủ kapcsolat látens változó négy dimenzióra bontható:

- az ügyintézés ideje és módja,

- az ügyfélszolgálati dolgozók munkájának értékelése,

- a számlázási tevékenység,

- a szolgáltató elérhetősége.

6. táblázat

Az üzemszerủ kapcsolat dimenzió faktorelemzése $\mathbf{2 0 0 0}$

\begin{tabular}{|l|c|c|c|}
\hline \multirow{2}{*}{ Kérdés tartalma } & \multicolumn{3}{|c|}{ Faktorok } \\
\cline { 2 - 4 } & 1 & 2 & 3 \\
\hline $\begin{array}{l}\text { Az ügyintézők szolgálatkészsége } \\
\text { megfelelő }\end{array}$ & 0,90 & & \\
\hline $\begin{array}{l}\text { Az ügyintézők udvariassága, türelme } \\
\text { megfelelő }\end{array}$ & 0,89 & & \\
\hline Az ügyintézés megbízhatósága & 0,88 & & \\
\hline Az ügyintézők rugalmasság megfelelő & 0,88 & & \\
\hline Az ügyintézők felkészültsége megfelelő & 0,82 & & \\
\hline $\begin{array}{l}\text { Az ügyintézés időtartama, gyorsasága } \\
\text { megfelelő }\end{array}$ & 0,68 & & \\
\hline $\begin{array}{l}\text { Az ügyfélszolgálati irodák megközelítése } \\
\text { megfelelő }\end{array}$ & & 0,83 & \\
\hline Az iroda nyitva tartása megfelelő & & 0,80 & \\
\hline A hibabejelentés lehetőségei megfelelőek & & 0,70 & \\
\hline A díjfizetés idôpontja megfelelô & & 0,62 & \\
\hline A számlázás korrekt, érthető & & & 0,82 \\
\hline A számlázás kellően részletezett & & & 0,78 \\
\hline
\end{tabular}

A magyarázott varianciák értéke $74 \%$, rendben 25 , 21,15 , és $12, \%$.

A két felmérés faktorelemzése alapján megállapítható, hogy az üzemszerű kapcsolat mérésére használt dimenziók hasonlóak, és jól kifejezik a latens változót, hiszen mindössze egy új faktort találtunk, és az olyan elemeket tartalmaz, amelyek egy része a korábbi felmérésben nem szerepelt.

Az összehasonlitó elemzés e dimenzióban megerösiti a mérés megbizhatóságát, és annak ellenére, hogy a fogyasztók kedvezőbben ítélik meg az üzemszerü kapcsolat elemeit 2002-ben, a faktoranalizis eredményei meggyözöek.
7. táblázat

Az üzemszerü kapcsolat dimenzió faktorelemzése 2002

\begin{tabular}{|l|c|c|c|c|}
\hline \multirow{2}{*}{ Kérdés tartalma } & \multicolumn{3}{|c|}{ Faktorok } \\
\cline { 2 - 5 } & 1 & 2 & 3 & 4 \\
\hline $\begin{array}{l}\text { Az ügyfélszolgálati irodán a } \\
\text { várakozási idő }\end{array}$ & 0,87 & & & \\
\hline $\begin{array}{l}\text { Az ügyfélszolgálati irodán a } \\
\text { várakozás módja }\end{array}$ & 0,87 & & & \\
\hline $\begin{array}{l}\text { Az ügyfélszolgálati irodán az } \\
\text { ügyintézés gyorsasága }\end{array}$ & 0,83 & & & \\
\hline $\begin{array}{l}\text { Az ügyfélszolgálati irodán az } \\
\text { ügyintézés egyszerűsége }\end{array}$ & 0,76 & & & \\
\hline $\begin{array}{l}\text { Az ügyfélszolgálati iroda } \\
\text { ügyintézőjének udvariassága }\end{array}$ & & 0,78 & & \\
\hline $\begin{array}{l}\text { Az ügyfélszolgálati iroda } \\
\text { ügyintézőjének megjelenése }\end{array}$ & & 0,78 & & \\
\hline $\begin{array}{l}\text { Az ügyfélszolgálati iroda } \\
\text { ügyintézójének felkészültsége }\end{array}$ & & 0,78 & & \\
\hline $\begin{array}{l}\text { Az ügyfélszolgálati iroda } \\
\text { ügyintézőjének azonosíthatósága }\end{array}$ & & 0,73 & & \\
\hline A számla pontossága & & & 0,84 & \\
\hline A számla érthetósége & & & 0,82 & \\
\hline $\begin{array}{l}\text { A havonta fizetendő összeg } \\
\text { megfelelősége a fogyasztásnak }\end{array}$ & & & 0,62 & \\
\hline $\begin{array}{l}\text { Az ügyfélszolgálati iroda } \\
\text { megközelíthetősége }\end{array}$ & & & & 0,85 \\
\hline Az ügyfélszolgálati iroda nyitva tartása & & & & \\
\hline
\end{tabular}

\section{A fogyasztói öntudat mérőskála eredményeltérései, és alkalmazhatóságának korlátjai}

Miután ez a dimenzió újonnan bevezetett, és a skálák a 2000. évi vizsgálatnál egydimenziójúnak bizonyultak, így a kontrollkutatásnál a mérő elemeket alig változtattuk, mindössze azokat a kérdéseket hagytuk ki, amelyek a korábbi felmérésben nem bizonyultak relevánsnak.

A fogyasztói tudatosságot három dimenzióban mértük, és az eredmények összehasonlítását is e három tényező alapján ismertetjük.

A kompetencia kapcsán azt vizsgáltuk, vajon a fogyasztó mennyire ismeri a szolgáltató, illetve saját jogait és kötelezettségeit, azaz mennyire jártas az általa igénybe vett szolgáltatás feltételeiben. (8. táblázat)

A 16 kérdés faktoranalízise négy faktort emel ki a tudatosság magyarázatából, ahol:

- az első faktor a kompetencia,

- a második az informáltság,

- a harmadik az érdekérvényesítés megjelenítője,

- a negyedik faktor tartalmilag nem kapcsolható a tudatosság változóhoz.

A négy faktor együttes magyarázó ereje $67 \%$, rendre $23,21,15$ és $8 \%$. 
8. táblázat

A tudatosság dimenzió faktorelemzése $\mathbf{2 0 0 0}$

\begin{tabular}{|c|c|c|c|c|}
\hline \multirow[b]{2}{*}{ Kérdés tartalma } & \multicolumn{4}{|c|}{ Faktorok } \\
\hline & 1 & 2 & 3 & 4 \\
\hline $\begin{array}{l}\text { Tisztában vagyok azzal, hogy a } \\
\text { szolgáltatónak milyen kötelezettségei } \\
\text { vannak velem szemben }\end{array}$ & 0.91 & & & \\
\hline $\begin{array}{l}\text { Tisztában vagyok azzal, hogy a } \\
\text { szolgáltatónak milyen jogai vannak } \\
\text { velem szemben }\end{array}$ & 0,91 & & & \\
\hline $\begin{array}{l}\text { Tisztában vagyok azzal, hogy milyen } \\
\text { kötelezettségeim vannak a } \\
\text { szolgáltatóval szemben }\end{array}$ & 0,89 & & & \\
\hline $\begin{array}{l}\text { Pontosan tudom, hogy milyen jogaim } \\
\text { vannak a szolgáltatóval szemben }\end{array}$ & $\mathbf{0 , 8 0}$ & 0,28 & & \\
\hline $\begin{array}{l}\text { Pontosan tudom, hogy ha problémám } \\
\text { van a szolgáltatással kapcsolatban, } \\
\text { mit kell tennem }\end{array}$ & 0,53 & 0,45 & & \\
\hline $\begin{array}{l}\text { Mindig könnyen megértem az írásban } \\
\text { kiküldött tájékoztatókat }\end{array}$ & 0,29 & 0,76 & & \\
\hline $\begin{array}{l}\text { Rendszeresen követem a szolgáltatók } \\
\text { reklámtevékenységét }\end{array}$ & 0,21 & 0,73 & & \\
\hline $\begin{array}{l}\text { Mindig alaposan elolvasom az írásban } \\
\text { kiküldött tájékoztatókat }\end{array}$ & 0,32 & 0,72 & & \\
\hline $\begin{array}{l}\text { Pontosan ismerem a szolgáltatás } \\
\text { díjtételeit }\end{array}$ & & 0,65 & 0,26 & \\
\hline $\begin{array}{l}\text { Pontosan ismerem a szolgáltatásokkal } \\
\text { kapcsolatos díjkedvezményeket }\end{array}$ & & 0,63 & 0,23 & \\
\hline Rendszeresen követem az újitásokat & & 0,62 & 0,20 & \\
\hline $\begin{array}{l}\text { Ha úgy érzem, hogy gondom van a } \\
\text { számlázással, azonnal reklamálok }\end{array}$ & & & 0,90 & \\
\hline $\begin{array}{l}\text { Ha a panaszomra nem kapok } \\
\text { megnyugtató orvoslást, további } \\
\text { lépéseket teszek }\end{array}$ & & & 0,88 & \\
\hline $\begin{array}{l}\text { Ha úgy érzem, hogy gondom van a } \\
\text { szolgáltatás minőségével, azonnal } \\
\text { reklamálok }\end{array}$ & & 0,23 & 0,71 & 0,39 \\
\hline $\begin{array}{l}\text { Rendszeresen ellenőrzöm az órák, } \\
\text { a fogyasztás állását }\end{array}$ & & 0,40 & 0,41 & 0,27 \\
\hline $\begin{array}{l}\text { Ha úgy érzem, hogy sok lesz a számla, } \\
\text { visszafogom a fogyasztást }\end{array}$ & & & & 0,85 \\
\hline
\end{tabular}

A 2002. évi felmérés elemzése a 9. táblázatban található faktorokat adta:

A három faktor együttes magyarázó ereje összesen, $69 \%$, rendre 34,21 és , $14 \%$.

A tudatosság dimenzió mérésére használt kérdések mindkét kutatásban jónak bizonyultak, a „,fogyasztás visszafogása" kérdés kihagyásával pedig a három tartalmilag jól értelmezhető - faktor magyarázza a látens változót:

- a kompetencia,

- az informáltság és

- az érdekérvényesítési hajlam.
9. táblázat

A tudatosság dimenzió faktorelemzése 2002

\begin{tabular}{|l|c|c|c|}
\hline \multirow{2}{*}{ Kérdés tartalma } & \multicolumn{3}{|c|}{ Faktorok } \\
\cline { 2 - 4 } & 1 & 2 & 3 \\
\hline $\begin{array}{l}\text { Tisztában vagyok azzal, hogy a } \\
\text { szolgáltatónak milyen kötelezettségei } \\
\text { vannak velem szemben }\end{array}$ & 0,88 & & \\
\hline $\begin{array}{l}\text { Pontosan tudom, hogy milyen jogaim } \\
\text { vannak a szolgálfatóval szemben }\end{array}$ & 0,86 & & \\
\hline $\begin{array}{l}\text { Tisztában vagyok azzal, hogy a } \\
\text { szolgáltatónak milyen jogai vannak } \\
\text { velem szemben }\end{array}$ & 0,86 & & \\
\hline $\begin{array}{l}\text { Tisztában vagyok azzal, hogy milyen } \\
\text { kötelezettségeim vannak a szolgáltatóval } \\
\text { szemben }\end{array}$ & 0,84 & & \\
\hline $\begin{array}{l}\text { Pontosan ismerem a szolgáltatásokkal } \\
\text { kapcsolatos díjkedvezményeket }\end{array}$ & 0,72 & & \\
\hline $\begin{array}{l}\text { Pontosan ismerem a szolgáltatás } \\
\text { díjtételeit }\end{array}$ & 0,70 & & \\
\hline $\begin{array}{l}\text { Ha a panaszomra nem kapok megnyug- } \\
\text { tató orvoslást, további lépéseket teszek }\end{array}$ & & 0,92 & \\
\hline $\begin{array}{l}\text { Ha úgy érzem, hogy gondom van } \\
\text { a számlázással, azonnal reklamálok }\end{array}$ & & 0,92 & \\
\hline $\begin{array}{l}\text { Ha úgy érzem, hogy gondom van } \\
\text { a szolgáltatással, azonnal reklamálok }\end{array}$ & & 0,85 & \\
\hline $\begin{array}{l}\text { Rendszeresen követem a szolgáltatók } \\
\text { reklámtevékenységét }\end{array}$ & & & 0,82 \\
\hline $\begin{array}{l}\text { Mindig alaposan elolvasom az írásban } \\
\text { kiküldött tájékoztatókat }\end{array}$ & & & 0,78 \\
\hline Rendszeresen ellenőrzi a méróóra állását & & & 0,60 \\
\hline
\end{tabular}

\section{A kommunikációs mérôskála faktorelemzése}

A kommunikáció tartalmára vonatkozóan a hazai fogyasztói kutatásokat alapul véve fogalmaztunk meg kérdéseket oly módon, hogy alapul vettük a már bevezettet skálákat, de azokon módosítottunk. A MEH vizsgálatban szereplő kérdések (tájékoztatás a díjakról, a szolgáltatás-kimaradásokról, a takarékos készülékek kiválasztásáról és üzemeltetéséről) (Rekettye et al., 1997) mellett a 2000-es vizsgálatban olyan kérdések is szerepeltek a kutatásban, mint pl. a jogokról, kötelezettségekről és a számlázásokról való informálás. Miután a 2000-ben vizsgált régióban csak a kutatás előtti 1-2 évben indult kampány a takarékos készülékekkel kapcsolatban, és a próbakérdezések során is érezhető volt, hogy az energiatakarékosság tekintetében még nem igazán tájékozottak a fogyasztók, ezért e kérdéseket mellőztük a felmérésben, ugyanakkor fontosnak tartottuk néhány helyi erőfeszítés eredményének mérését. Így került be a tételek közé a „Mindennap Szolgáltatók Magazinjának" olvasottsága, illetve a szolgáltatóról a helyi sajtóban megjelenő írások követése. (A „Mindennap 
Szolgáltatók Magazinja" egy, a közszolgáltatók által közösen kiadott ingyenes tájékoztató újság volt.) A kapcsolattartás formájának preferálását az interjúk hatására mértük, ugyanis a beszélgetésekből kiderült, hogy a cégek számára fontos volt annak ismerete, vajon az ügyfelek a személyes vagy a telefonos kapcsolattartást részesítik-e előnyben (10. táblázat).

10. táblázat

A kommunikációs és informálódási dimenziók faktorelemzése $\mathbf{2 0 0 0}$

\begin{tabular}{|l|c|c|c|c|}
\hline \multirow{2}{*}{$\begin{array}{l}\text { Kérdés tartalma } \\
\text { Szolgáltató informál }\end{array}$} & \multicolumn{4}{|c|}{ Faktorok } \\
\cline { 2 - 5 } & 1 & 2 & 3 & 4 \\
\hline - az új szolgáltatásokról & $\mathbf{0 , 8 5}$ & & & \\
\hline - az ügyfél jogairól és kötelezettségeiről & $\mathbf{0 , 8 1}$ & & 0,21 & \\
\hline - a díjkedvezményekról & $\mathbf{0 , 8 0}$ & & & \\
\hline - az árak változásáról & $\mathbf{0 , 8 0}$ & & & \\
\hline - a szolgáltató jogairól és & & & & \\
\hline kötelezettségeirôll & $\mathbf{0 , 8 0}$ & & 0,21 & \\
\hline - a számlázás körülményeiról & $\mathbf{0 , 7 8}$ & 0,21 & & \\
\hline - a várható szolgáltatás-kimaradásról & $\mathbf{0 , 4 6}$ & 0,39 & $-0,30$ & 0,25 \\
\hline $\begin{array}{l}\text { A hírlevelek hasznos információkat } \\
\text { tartalmaznak }\end{array}$ & 0,46 & $\mathbf{0 , 6 7}$ & & \\
\hline $\begin{array}{l}\text { Az ügyfélszolgálati irodákban mindig } \\
\text { tájékoztatnak az aktuális akciókról }\end{array}$ & 0,21 & $\mathbf{0 , 6 6}$ & & \\
\hline A „Mindennap" Magazint olvasom & & $\mathbf{0 , 6 5}$ & $-0,44$ & \\
\hline $\begin{array}{l}\text { A szolgáltatóról a helyi sajtóban meg- } \\
\text { jelenő cikkeket mindig elolvasom }\end{array}$ & & $\mathbf{0 , 6 2}$ & & \\
\hline $\begin{array}{l}\text { A szolgáltató által kibocsátott és a szám- } \\
\text { lákhoz csatolt leveleket mindig elolvasom }\end{array}$ & 0,28 & $\mathbf{0 , 6 0}$ & & \\
\hline $\begin{array}{l}\text { A reklám jó eszköz a fogyasztók } \\
\text { befolyásolására }\end{array}$ & & 0,20 & $\mathbf{0 , 8 2}$ & \\
\hline $\begin{array}{l}\text { Ha tehetem, a szolgáltatóval személyesen } \\
\text { tartom a kapcsolatot }\end{array}$ & & 0,30 & & $\mathbf{0 , 8 0}$ \\
\hline $\begin{array}{l}\text { Ha tehetem, a szolgáltatóval telefonon } \\
\text { tartom a kapcsolatot }\end{array}$ & & 0,56 & & $\mathbf{- 0 . 6 0}$ \\
\hline
\end{tabular}

A faktorelemzés alapján a látens változót leíró elemek négy faktorba különíthetők el, amelyek tartalmilag is jól magyarázhatók. Az első faktorba kerültek a kommunikációs erőfeszítésekkel kapcsolatos tételek, a másodikba a tájékoztatási tevékenység hatékonyságát mérő elemek, míg a harmadik faktorban egyedül szerepel a reklám megítélése. A magas faktorsúly arra utal, hogy a reklámeszközök hatással «annak a latens változóra, de különálló dimenzióként kell kezelni ezt a tételt (11. táblázat).

A sajátértékek és a magyarázott varianciák alapján látható, hogy az első faktor hatása erős, hiszen önmagában 30\%-ot magyaráz a szórásból, a négy faktor együttesen pedig csaknem $65 \%$-át jeleníti meg a látens változónak. (12. táblázat)
A magyarázott variancia 2002-ben 69\%. A két felmérés eredményei az eltérő kérdések miatt nehezen hasonlíthatók össze, de a faktorok az országos felmérésben is jól értelmezhetők:

- az első faktorban a Hírlevéllel kapcsolatos vélemények jelennek meg,

- a másodikban a kommunikációs erőfeszítések lakossági követése,

- a harmadikban pedig az internetes és írásos tájékoztatók fontossága.

11. táblázat

A kommunikációs és informálódási dimenziók varianciái 2000

\begin{tabular}{|c|c|c|c|}
\hline & \multicolumn{3}{|c|}{ Rotáció utáni magyarázott variancia } \\
\hline Faktorok & Saját érték & $\begin{array}{c}\text { Magyarázott } \\
\text { variancia }\end{array}$ & $\begin{array}{c}\text { Kumulált } \\
\text { variancia }\end{array}$ \\
\hline 1 & 4,54 & 30,26 & 30,26 \\
2 & 2,75 & 18,35 & 48,60 \\
3 & 1,22 & 8,16 & 56,77 \\
4 & 1,18 & 7,84 & 64,60 \\
\hline
\end{tabular}

12. táblázat

A kommunikációs és informálódási dimenziók faktorelemzése $\mathbf{2 0 0 2}$

\begin{tabular}{|l|c|c|c|}
\hline \multirow{2}{*}{$\begin{array}{l}\text { Kérdés tartalma } \\
\text { Mennyire elégedett: }\end{array}$} & \multicolumn{3}{|c|}{ Faktorok } \\
\cline { 2 - 4 } & 0,94 & 2 & 3 \\
\hline A Hírlevél külalakjával & 0,94 & & \\
\hline A Hírlevél küldésének gyakoriságával & 0,93 & & \\
\hline A Hírlevél tartalmával & & & \\
\hline Mennyire fontos Önnek: & 0,56 & & \\
\hline A Hírlevél a számla mellett & & & \\
\hline $\begin{array}{l}\text { Mennyire igazak Önre az alábbi } \\
\text { állítások: }\end{array}$ & & 0,72 & \\
\hline $\begin{array}{l}\text { Rendszeresen követi a szolgáltató } \\
\text { reklámtevékenységét }\end{array}$ & & 0,71 & \\
\hline $\begin{array}{l}\text { Alaposan elolvassa az írásos } \\
\text { tájékoztatókat }\end{array}$ & & 0,68 & \\
\hline $\begin{array}{l}\text { Rendszeresen ellenőrzi a fogyasztása } \\
\text { (méróóra) állását }\end{array}$ & & & \\
\hline Mennyire fontos Önnek: & & & 0,86 \\
\hline Az internetes honlap & & & 0,76 \\
\hline A szórólapok, kiadványok & & \\
\hline
\end{tabular}

\section{Összegzés}

A két felmérés eredményei jelzik, hogy a lakossági lojalitás vizsgálata az energiaszektorban részben igazolja az alkalmazott modell dimenzióinak létjogosultságát, másrészt azonban arra is figyelmeztetnek, hogy a mérési modellt, az alkalmazott skálákat és a 
mérési módszereket érdemes tovább finomítani. A lojalitás dimenzió faktorelemzése ugyan nem egyezik a két évvel korábban kapott eredményekkel, az árérzékenység változói azonban továbbra is egy faktorban jelennek meg. Mindkét kutatás eredményei arra figyelmeztetnek, hogy ebben a szférában valószínúleg újra kellene gondolni a lojalitás definiálását és annak operacionalizálását is. Kétségtelen, hogy miután egyelőre csak kényszerhűségről beszélhetünk, a kutatási eredmények nem tekinthetők megbízhatónak, az azonban várható, hogy a közelgő piaci liberalizáció szükségessé teheti a fogyasztók megtartásának további vizsgálatait, ez pedig elengedhetetlenné teszi a lojalitás szolgáltatás-specifikus definiálását és mérési módszereinek modellezését. (Bár a két kutatás csak a lakossági fogyasztók lojalitásának mérésére irányult, megjegyezzük, hogy a B2B kapcsolatokban valószínűleg eltérő modelleket célszerű alkalmazni.) Szinte biztosnak látszik, hogy a lojalitás mérésére használt kérdések ebben a szférában felülvizsgálatra szorulnak, és az is biztos, hogy a hagyományos minőségelemek mellett más kérdések megfogalmazása is szükséges.

Az önálló vizsgálati dimenzióként kezelt üzemszerű kapcsolatok (számlázás és ügyfélszolgálat) longitudinális kutatás faktorelemzései jelzik, hogy a mérőskálák nem egydimenziójúak, a változók azonban közel azonos elkülönüléseket mutatnak, és ezek a faktorok tartalmilag jól leírhatók. Nagyon bíztatóak az eredmények a vizsgálati modellben új dimenzióként bevezetett fogyasztói öntudattal kapcsolatban. Annak ellenére, hogy a fogyasztói kompetencia és az informáltság csökkent, nőtt az érdekérvényesítési hajlandóság, a faktorelemzések pedig a változók azonos elkülönüléseit jelzik. A kapcsolatiság és a kommunikációs dimenziók változóira kapott eredmények is pozitívak.

A longitudinális kutatás eredményeit összegezve az alábbi megállapításokat tehetjük:

Módszertani szempontból igazolódott, hogy a társadalomkutatásoknál sem a megbízhatósági, sem a validitási követelmények nem biztosíthatók maradéktalanul: a kutatás körülményei folyamatosan változnak, a kérdések jelentéstartalma függ azok megfogalmazásától, sorrendjétől, a kérdezés módjától. A konkrét vizsgálatok újra felhívták a figyelmet arra, hogy a külföldi szakirodalomban és kutatásokban több helyen sikerrel használt lojalitást mérő elemek nem biztos, hogy eredményesek a közüzemi szolgáltatások fogyasztói hűségének kutatásánál. Úgy tűnik, hogy a „mit tesz a fogyasztó” (elpártol, marad, újravásárol stb.) kérdések helyett célszerűbb lenne azt vizsgálni, hogy miért tesz valamit a fogyasztó, azaz sokkal inkább motivációkutatásokra, és a kvantitatív felmérések mellett kvalitatív vizsgálatokra kellene koncentrálni. További módszertani kérdés, hogy a tradicionálisnak tekinthető minőségi paraméterek elegendőek-e a közüzemi szolgáltatások minőségmérésére. Itt is kétségeink vannak, ugyanis mindkét kutatás eredményei jelzik, hogy a minőségváltozók más faktorokba különülnek el, mint azt a nemzetközi kutatásokból ismerjük. Megítélésünk szerint a nemzetközileg elfogadott szolgáltatás-minőség mérési modellje és módszertana az általunk vizsgált ágazatban nem használható, azaz a modell nem általánosítható.

Tartalmi szempontból fontos eredménynek tartjuk, hogy a lojalitás mérésére bevezetett új dimenziók (fogyasztói öntudat, kapcsolatiság) mindkét kutatás eredményei alapján relevánsnak tekinthetők.

Az igazi nagy kérdőjel azonban az, hogy valóban jövedelmezőséget eredményez-e a lojalitás, hogy a hűséges fogyasztói bázisért tett erőfeszítések megtérülnek-e? Ehhez további kutatásokra, és a cégek együttműködésére van szükség.

\section{Felhasznált irodalom}

Berry, L. L. (1980): Services Marketing is Different. Business Magazine, May-Jun, pp. 24-29.

Grönroos, C. (1984): A Service Quality Model and its Marketing Implications. European Journal of Marketing, Vol. 18. Ápr. p. 36-44.

Cronin, J. J. - Taylor, S. T. (1992): Measuring Service Quality: A Reexamination and Extention. Journal of Marketing, 56 Jul/Aug. p. 55-68.

Gummesson, E. (1994): Making relationship marketing operational. International Journal of Service Industry Management, 5 (5) p. 5-20. (In: Kandampully, 1998.)

Fojtik, J. - Farkas, L. (2001): Minőség és marketing: a pénzintézeti szolgáltatások példája. Vezetéstudomány. 10. sz.

Fornell, C. - Wernerfelt, B. (1987): Defensive Marketing Strategy by Customer Complaint Management. Journal of Marketing Research, 24. Nov. p. 337-346. (In: Oliver, 1999.)

Gallup Quality of Service Audit (1994): www. gallup. hu. /GALLUP/self/qsa/gsatext/qsa3.htm

Grönholdt, L. - Martensen, A. - Kristensen, K. (2000): The relationship between customer satisfaction and loyalty: crossindustry differences. Total Quality Management, Vol. 11, Nos, 4/5\&6, p. 509-514.

Hetesi, E. (2001): A marketingmunka dolgozói megítélésének, valamint a lakossági fogyasztók lojalitásának mérése és elemzése a hazai közüzemi szolgáltatóknál. PhD disszertáció, 2001, PTE, KTK

Hetesi, E. (2002): Új dimenziók a lojalitás mérésében. Marketing \&Menedzsment. 4. sz. p. 35-41.

Hetesi, E. (2003): A minőség, az elégedettség és a lojalitás mérésének problémája a szolgáltatásoknál, és azok hatása a jövedelmezôségre. Marketing \&Menedzsment. 5. sz. p. 42-50. 
Hofmeister-Tóth, Á. - Simon, J. - Sajtos, L. (2003): Fogyasztói elégedettség. Alinea Kiadó, Budapest

Jones, T. O. - Sasser, Jr. W. E. (1995): Why satisfied customer defect? Harvard Business Review, Nov/Dec, Vol. 73. Issue 6.

Kandampully, J. (1998): Service quality to service loyalty: A relationship which goes beyond customer services. Total Quality Management, Aug. Vol. 9. Issue 6, p. 431, p.13.

Martensen, A. - Grönholdt, L. - Kristensen, K. (2000): The drivers of customer satisfaction and loyalty: cross industry findings from Denmark. Total Quality Management, Vol. 11, Nos, 4/5\&6, p. 544-553.

Neal, W. D. (1999): Satisfaction is Nice, But Value Drivers Loyalty. Marketing Research, Spring, Vol. 11. Issue. 1.

Némethné, Pál K. (2000): A vevői elégedettség mérésének szerepe és története. Marketing \&Menedzsment, 2000. 2. sz. 45-51 o.

Oliver, R. L. (1999): Whence Consumer Loyalty? Journal of Marketing. Vol. 63. (Special Issue) p. 33-44.

Parasuraman, A. - Zeithalm, V. A. - Berry, L. L. (1991): Understanding customer expectation of service. Sloan Management Review, Spring, p. 39-48.

Parasuraman, A. - Zeithalm, V. A. - Berry, L. L. (1985): A conceptual model of service quality and its implications for future research. Journal of Marketing, 49. p. 41-50.

Parasuraman, A. - Zeithalm, V. A. - Berry, L. L. (1988): SERVQUAL: a multiple-item scale for measuring consumer perceptions of service quality. Journal of Retailing, 64, p.12-40.

Reicheld, F. F. - Sasser, W. E. (1990): Zero Defections: Quality Comes to Services. Harvard Business Review, 8. Sept/Okt

Reicheld, F. F. (1996): The Loyalty Effect. Boston, MA: Harvard Business School Press.
Rekettye G. - Tersztyánszky T. (1997): A villamosenergia-fogyasztók elégedettségének mérése. Marketing \&Menedzsment. 1. sz. 4-8. o.

Rekettye G. - Orosdy B. - Tersztyánszky T. (1997): Villamosenergia-szolgáltatás és fogyasztói elégedettség. Marketing\& Menedzsment. 3. sz. 4-10. o.

Orosdy, B - Rekettye, G. (2003): A fogyasztói elégedettség mérésének továbbfejlesztése a hazai villamosenergia szolgáltatóknál. A közszolgáltatások marketingje és menedzsmentje. 195205. o. Szerk. Hetesi Erzsébet, Szegedi Tudományegyetem, Gazdaságtudományi Kar, JATEPress, Szeged

Rekettye, G. (2000): Fogyasztói közérzet-2000. Marketing\& Menedzsment, 6. sz. 7-11. o.

Rekettye,G. - Hetesi, E. (2001): A lakossági fogyasztók lojalitásának mérése és elemzése egy közép-kelet-európai energiaszolgáltató szervezetnél, Vezetéstudomány, 9. sz. p. 17-25

Szántó, Sz. (2003): Fogyasztói elégedettség az elmélet és a gyakorlat szempontjából. Marketing \&Menedzsment. 5. sz. 26-41. o.

Veres, Z. - Hetesi, E. (2003): Mit kezdjen a marketing a minőségmenedzsment új tendenciáival? Totális marketing, avagy a marketing kiteljesedése. Magyar Marketing Múhelyek IX. Konferenciája, Keszthely, 292-306. o

Vollmer, I. - Johnson, M. - Herrmann, A. - Huber, F. (2000): The Loyalty of Dissatisfied Customers: Determinants and Impications. XXV Annual Coloquium on Research in Economic Psychology and SABE 2000 Conference, Baden, Vienna/ Austria

Zeithaml, V. A. (2000): Service Quality, Profitability, and the Economic Worth of Customers: What We Know and What We Need to Learn? Journal of the Academy of Marketing Science, Winter, Vol. 28. Issue 1. 